houses have been built in England and Wales. The spread of leisure has led to a marked expansion in entertainment and sport, while changes in social and domestic habits account for the development of bus travel, the growth of restaurant and hotel businesses and the expansion of laundry and similar trades which provide services formerly carried on in the home.

The new manufacturing industries are much more numerous than is commonly supposed, though the development of many of them is hidden under the generic names in the Ministry of Labour's list. In the development of new industries, or the recent expansion of the old-established trades, scientific discovery or the application of science has played an important part. A long list of such products could be given, but it must suffice to mention rayon; aircraft; motor-cars ; electric cables, lamps, motors and apparatus; radio ; neon signs; photo-electric apparatus; pharmaceutical chemicals; detergents; synthetic resins and other plastic materials ; cinematograph films ; refrigerators; solid carbon dioxide; chromium plating; cellulose products; and canned foods. Indeed, the extent to which scientific research is transforming methods of production is seldom fully realised, and, as was stated in a report of the Department of Scientific and Industrial Research, "in nearly every industry to-day, movements are on foot to apply old materials to new uses or to discover uses for new products".
In rayon, the relation of science to industry is conspicuously close, and this industry has made rapid progress in those countries which possessed a well-developed chemical industry. Other thriving new-comers are the plastic industries; the products of which are now extensively utilised not only for accessories of all kinds, but also in the manufacture of silent gear wheels and in chemical engineering, where their resistance to boiling acids and corrosive fumes are of value. Canning is another industry which has recently made rapid progress in Great Britain ; expanding its production from about 2-3 million cans in 1925 to more than 100 million cans in 1931. Special problems had to be overcome on account of the high acid content of British fruit, and the difficulties in preserving the colour and flavour. Many ingenious machines have been constructed by British manufacturers for this industry.

In connexion with the building-up of new export trades, scientific applications are an essential asset. Specialised products, combining high quality with skilled workmanship, are frequently assured of a ready sale overseas, such as has been achicved by British manufacturers of light aeroplanes, motor-cars and electrical apparatus. An interesting illustration of the advantages of scientific specialisation in export industries is the almost exclusive utilisation of British photographic and projection lenses in the film studios of Hollywood.

\title{
The Professors of the Royal Institution
}

\section{By Thomas Martin}

$\mathrm{B}^{\mathrm{Y}}$ $Y$ the election on May 7 of Sir James Jeans as professor of astronomy in the Royal Institution, its members have exercised a privilege which has not been used since 1863. Faraday was then the Fullerian professor of chemistry, but he was in his declining years, and Dr. (afterwards Sir Edward) Frankland was elected to a separate professorship of chemistry. Frankland discharged the duties until shortly after Faraday's death in 1867, when Odling became the Fullerian professor and Frankland's professorship was allowed to lapse. The other 'elected' professorship in the Institution at the time, that of natural philosophy, had been established ten years earlier; and was not so short-lived. It was created for John Tyndall when he went to the Institution in 1853, to become the friend and colleague of Faraday in the last fourteen years of his life; and it has continued by election and re-election to the present day.

Lectures on scientific subjects, to be given in a lecture room with the most up-to-date facilities for experiment and demonstration, were a part of the original scheme drawn up in 1799 by the founder, Benjamin Thompson, Count Rumford; and when Rumford's proposals were adopted and the Royal Institution of Great Britain came into existence, the "teaching by courses of philosophical lectures and experiments the application of science to the common purposes of life" was recited as one of its objects in the Royal Charter granted by King George III. The lecture room was constructed, under Rumford's personal supervision, at the house which had been purchased in Albemarle Street; and the procedure to be followed in appointing professors and lecturers was laid down in the by-laws given to the new Institution. The professors were to be elected annually by ballot, and a new professorship could be established at any time, by resolution proposed by fifteen members, which must be carried at one general monthly meeting and confirmed at the next. 
The first of the Royal Institution professors was Dr. Thomas Garnett. Trained as a physician, Garnett had already established a reputation in his profession and as lecturer at Anderson's Institution in Glasgow when, in 1799, he accepted the invitation conveyed by Rumford to join the new institution in London. He was elected professor of natural philosophy and chemistry, and on his arrival in December, entered with enthusiasm on his varied duties; but his tenure was not destined to be a long one. After some initial success with his London audience, he found himself handicapped by ill-health, by a certain diffidence as to his own powers, and by his north country accent. Moreover, he worked under the critical eye of Count Rumford, who lived at the Institution at the time, and personally supervised every detail of its activities. It is not surprising that causes of difference appeared. In Rumford's view the lectures given by the professors were those they were requested to give, and the experiments they made were those they were directed to make, by the Managers and the various committees. The work of the professors was but a part of the whole. The Institution, with its library, its workshops, its school for training workmen and mechanics, its repository for models and inventions, was formed for "diffusing the knowledge and facilitating the general introduction of useful mechanical inventions and improvements". It was a part of the philanthropical activity of the day, an attempt to bring to the working classes a knowledge of the useful applications of science.

Garnett found the difficulties of his position too great for him ; and resigned his professorship in June 1801. Before he left, a lecturer in chemistry was appointed to share the work. Rumford, writing of the new appointment to his daughter Sarah, in America, said : "We have found a nice able man for his place as lecturer, Humphry Davy"; and in March 1801, Davy was brought from Dr. Beddoes' Pneumatic Institution at Bristol, the place of his experiments on nitrous oxide, to begin the career of exposition and research which was to bring fame to himself and to the Institution in which he worked.

To begin with, Davy, then only twenty-three years of age, was in a junior position; and when Garnett resigned, a new professor of natural philosophy was elected, the Quaker physicist, physician and Egyptologist, Thomas Young. Thus, almost at the outset, the Royal Institution had associated in its work two men, Young and Davy, whose names are among the greatest in English science. Young was engaged at the time on those papers on the theory of light and colours, in which he states his conclusion that "radiant light consists in undulations of the lumniferous ether" and explains the phenomena of interference by means of the wave theory. Although Young was, according to Davy, a most amiable and goodtempered man, his somewhat severe and didactic manner as a lecturer gave him no great success with popular audiences. He held his professorship for only two years, and then retired, to devote himself to his medical work and other pursuits.

Davy became the professor of chemistry, and his work, more than that of any other man, determined the lines on which the Royal Institution was to develop. In the lecture theatre, he possessed all those qualities which Young lacked. He infected his audiences with his own enthusiasm. Such was the charm of his personality and the eloquence of his discourse that he made his scientific lectures one of the fashionable amusements of London. Interest in him was heightened by the discoveries he soon began to make in the laboratory, in particular, those on chemical decomposition by means of the electric current, which enabled him to prepare sodium, potassium and other elements, until then unrecognised. Later came the Continental tour, with Faraday as his assistant, and the discovery of iodine in Paris; and, on his return to the Institution, the invention of the wire gauze safety lamp for miners.

Davy's activities in the laboratory and the lecture theatre established the traditions which have ever since characterised the work of the Royal Institution, of research inspired and largely carried on by the resident professor, and exposition, aided by all the resources of experiment, in terms suited to the layman as well as to the man of science. The Institution continued to attract the "higher ranks of society" whom the early Managers had wished to interest in it as a missionary enterprise depending on their support; but it became also a scientific centre, a place of original research in the problems of pure science which interested the professors. Its scope had become at once wider and narrower than the original intention. The training of mechanics, the construction of kitchens, of models, and other measures for introducing scientific improvements for the benefit of the lower classes, were dropped ; although the Managers responsible for the change consoled themselves with the thought that the poor must surely benefit indirectly from the useful activities to which the upper classes of the metropolis could now devote their leisure. Count Rumford, soon after Davy's arrival, had fallen out with the other Managers, and gone to live in Paris, whence he grumbled by letter to Sir Joseph Banks at the change of plan in the institution he had founded.

Davy continued in his professorship until 1813. In the previous year he had been knighted by the 
Prince Regent, and now, on his marriage to the wealthy Mrs. Apreece, went to live away from Albemarle Street. He was made honorary professor, and although he gave no lectures, continued to work in the laboratories for some years after. Early in this year he did one of his greatest services to the Institution by engaging Michael Faraday, a bookbinder's apprentice who had shown some interest in science, as his assistant.

The new assistant soon proved his worth, and began the progress which made him eventually Davy's successor, and the connexion with the Royal Institution which was to extend over fiftyfour years. His duties were to assist Sir Humphry in his researches and to attend on the other professor and lecturers. W. T. Brande had taken Davy's place as professor of chemistry, and Faraday's first opportunity of demonstrating his powers as a lecturer in the Institution came some years later, when he was called upon to take Brande's place in an emergency.

Faraday's training in his years as Davy's assistant made of him a good chemist and a skilled experimenter. His first attempts at research of his own were naturally on chemical problems, and early successes were the discovery of new compounds, including in particular "bicarburet of hydrogen" (benzene). The news of Oersted's experiments at Copenhagen set Davy to work on electromagnetism, and stimulated scientific interest all over Europe. Faraday, following the developments closely (since his tour in 1813-15 in France and Italy with Davy he knew some of the men whose papers he was reading), had by 1821 made his own contribution to the subject by his discovery of the electro-magnetic rotations. It was the beginning of his electrical researches.

The audiences in the lecture theatre discovered, too, that the young assistant had powers of his own. Brande, who retained his professorship until 1852, was not, it seems, an inspiring lecturer. Faraday, whose methods were less impulsive than those of Davy, had fluency and address at the lecture table, with a genius for apt experiment, and as the years went by he outshone his former master in his ability to fill the lecture theatre and stir in his audience some reflection of his personal enthusiasm.

In 1833 a new professorship was established, of a different kind from the others. John Fuller, a wealthy landowner and member of Parliament, made a gift of money for the endowment of what was called the Fullerian professorship of chemistry, the appointments to which were to be made by the Committee of Managers, and were not subject to annual re-election by the members. Faraday became the first Fullerian professor, and occupied the chair until his death in 1867.
It is difficult to speak of Faraday's professorship in a few words. It may be said that for nearly forty years, from the moment when in 1825 he became Director of the Laboratory following Davy's statement that "he considered the talents and services of Mr. Faraday, assistant in the laboratory, entitled to some mark of approbation from the Managers", he carried the Institution on his shoulders. He upheld and extended the traditions which Davy had originated. Two of the characteristic activities, the Friday evening discourses and the Christmas juvenile lectures, owe their inception almost entirely to Faraday. To his audiences, he was without a rival in his mastery of the arts of exposition and demonstration by experiment. His discovery of electromagnetic induction and his researches in electro-chemistry and electrostatics made him the first man of science of his age.

Fuller had endowed a second professorship in 1834, of physiology. Unlike that of chemistry, the Fullerian professorship of physiology was to be held for a fixed term of three years. P. M. Roget was the first professor, and he has been followed by a line of distinguished men. The list includes the names of T. H. Huxley, Sir Richard Owen, Sir Michael Foster, Sir Edwin Ray Lankester, and more recently Sir Charles Sherrington, Sir Arthur Keith and Sir Grafton Elliot-Smith.

Tyndall owed his connexion with the Institution to the favourable impression he made when, as a young physicist of promise, after a period of work in Germany, he was invited to give a Friday evening discourse. His election in May 1853 as professor of natural philosophy followed, and the later years at least of his professorship must be within the memory of many now living. It is said that he and Faraday worked together in the closest harmony, and that the relations of the older to the younger man resembled those of a father to a son. On Faraday's death in 1867, Tyndall followed him as the resident professor, and lived at the Institution until his retirement in 1887. He did valuable experimental work on the radiation and absorption of heat by gases and vapours, and his discovery that bacteria will not breed in dust-free air has been of great importance ; his work on sound was done as scientific adviser to the Trinity House, in which office he succeeded Faraday. He is perhaps best remembered as an expositor, for his animation and lucidity as a lecturer and for the felicity of his style as a popular writer on science.

William Odling, who succeeded Faraday as Fullerian professor of chemistry, resigned in 1873, after five years. He was followed, for another period of five years, by Dr. J. H. Gladstone, who in turn was succeeded, in 1877, by Professor 
(afterwards Sir James) Dewar. This was the beginning of another long tenure, for Dewar held the professorship for forty-six years, until his death in 1923 ; and from 1887, after Tyndall's retirement, he lived at the Institution as the resident professor.

Dewar's matchless skill as an experimenter, the fame of his researches, and of his Friday evening lectures with their carefully prepared and rehearsed demonstrations, are well known and remembered. In the Royal Institution laboratories, with apparatus often on an engineering scale, he liquefied the so-called permanent gases, and produced them for the first time-oxygen, hydrogen and air-in quantities sufficient for experiments on the properties of materials at the very low temperatures he reached; he invented, as a container for the cooled gases, the 'thermos' or Dewar flask; and he developed the method, of great technical importance, of making high vacua by using the great absorbing power for gases of charcoal cooled in liquid air. These are but the best known among his achievements. To quote the words of a distinguished contemporary : "He was . . . in no way less successful than his predecessors,
Young, Davy and Faraday, in adding to the reputation these pioneers created for the Royal Institution as a centre of scientific discovery and invention". It may be added that the recent lamented death of Lady Dewar is a reminder that not the least important of the Dewars' services to science was given as host and hostess in their house at the Institution.

Since Tyndall, three physicists of great distinction have held the professorship of natural philosophy who have also been, in turn, the Cavendish professor of physics at Cambridge. The late Lord Rayleigh, soon after his retirement from Cambridge, accepted the invitation to the chair at the Royal Institution, and held it until 1905 ; when he was succeeded by Sir J. J. Thomson. The present professor, Lord Rutherford, took up the duties in 1921. The rules prescribed at the beginning of the Institution for the election of professors are still followed; and thus it is that Lord Rutherford, as an 'elected' professor, must seek the suffrages of the members once a year, while Dewar's successor in the endowed Fullerian professorship of chemistry, the present resident professor, Sir William Bragg, does not do so.

\section{Obituary}

Mr. C. F. Cross, F.R.s.

$\mathrm{M}$ R. Charles Frederick Cross, who died in his eightieth year on April 15 at Hove, where he had lived in retirement for some years, left us indebted to him for a life devoted to a most difficult and unpromising branch of chemical research, rewarded by an epoch-making discovery, which is represented in Great Britain to-day by an artificial silk industry with a market capitalisation of more than $\mathfrak{f} 70,000,000$. $\mathrm{He}$ was educated at King's College, London, the University of Zurich and Owens College, Manchester. In 1879 , his work on the cellulose group commenced with a study of jute, and later, in association with Mr. E. J. Bevan and Mr. C. Beadle, he started the well-known business of Cross and Bevan, consultants to the paper trade.

It is difficult to estimate the number of papers on the chemistry of cellulose published by Cross and his collaborators; these date from 1880 until 1920, and appeared in the Journal of the Chemical Society, Journal of the Society of Dyers and Colourists, Berichte, Phil. Mag., Bull. Soc. Chim., and many lessknown publications. In these and in his textbooks, he has left us a mine of information and, as Prof. H. E. Armstrong has pointed out, the mystic character of some of his explanations must be ascribed to the intangible nature of his subject. Fulfilling the functions that it does in the plant, cellulose is on the border-line of living substances itself, and is liable to alter with every change in conditions to which it is subjected. His suggestion that it is an 'amphoteric electrolyte' hides a complexity of behaviour that has not been much illuminated by more modern advances in chemical language.

In 1892, Cross discovered that, by virtue of the alcoholic properties of cellulose, a soluble xanthate could be obtained on reaction with caustic soda and carbon disulphide. Working at Kew with Stearn and Topham, who were at first interested in the application of the new discovery to the manufacture of electric lamp filaments, the practical difficultios in spinning a continuous textile fibre were overcome, and the viscose silk industry was born.

At first, the solution of cellulose xanthate was expressed through a number of fine holes into a solution of ammonium sulphate, and the use of an acid bath, which resulted in the formation of a cellulose thread in one operation, was not arrived at until years later. The reception of the thread in a centrifugal box, which collected, drained and twisted it in one operation, due to Topham, has remained the standard practice up to the present day. In 1905, manufacture was started by the firm of Courtauld at Coventry, and the writer, then in charge of the chemical department, has a lively recollection of Cross, who took a great interest in the new venture, with his interesting suggestions, cheery sporting manner, wide culture and artistic interests.

Recognition of the value of Cross's work came later ; in 1917 he was elected fellow of the Royal Society, in 1916 he received the medal of the Society of 